\title{
Storage Root Yield of Sweetpotato as Influenced by Sweetpotato leaf curl virus and Its Interaction With Sweetpotato feathery mottle virus and Sweetpotato chlorotic stunt virus in Kenya
}

\author{
Bramwel W. Wanjala, ${ }^{1,2}$ Elijah M. Ateka, ${ }^{2}$ Douglas W. Miano, ${ }^{3}$ Jan W. Low, ${ }^{1}$ and Jan F. Kreuze ${ }^{4, \dagger}$ \\ ${ }^{1}$ Sub-Saharan Africa Regional Office, International Potato Center, 00603 Nairobi, Kenya \\ ${ }^{2}$ School of Agriculture, Jomo Kenyatta University of Agriculture and Technology, 00200 Nairobi, Kenya \\ ${ }^{3}$ Department of Plant Science and Crop Protection, University of Nairobi, 00100 Nairobi, Kenya \\ ${ }^{4}$ International Potato Center, La Molina Apartado Postal 1558, Lima, Peru
}

\begin{abstract}
In this study, the effect of a Kenyan strain of Sweetpotato leaf curl virus (SPLCV) and its interactions with Sweetpotato feathery mottle virus (SPFMV) and Sweetpotato chlorotic stunt virus (SPCSV) on root yield was determined. Trials were performed during two seasons using varieties Kakamega and Ejumula and contrasting in their resistance to sweetpotato virus disease in a randomized complete block design with 16 treatments replicated three times. The treatments included plants graft inoculated with SPLCV, SPFMV, and SPCSV alone and in possible dual or triple combinations. Yield and yield-related parameters were evaluated at harvest. The results showed marked differences in the effect of SPLCV infection on the two varieties. Ejumula, which is highly susceptible to SPFMV and SPCSV, suffered no significant yield loss from SPLCV
\end{abstract}

Abstract infection, whereas Kakamega, which is moderately resistant to SPFMV and SPCSV, suffered an average of $47 \%$ yield loss from SPLCV, despite only mild symptoms occurring in both varieties. These results highlight the variability in yield response to SPLCV between sweetpotato cultivars as well as a lack of correlation of SPLCV-related symptoms with yield reduction. In addition, they underline the lack of correlation between resistance to the RNA viruses SPCSV and SPFMV and the DNA virus SPLCV.

Keywords: Africa, begomovirus, crinivirus, cultivar/resistance, disease management, potyvirus, SPFMV, SPLCV, SPCSV, sweepovirus, treatment, yield
Ranked seventh in global food crop production, sweetpotato (Ipomoea batatas) is the third most important root and tuber crop after potato and cassava. In the developing world, sweetpotato ranks fourth in importance after rice, wheat, and corn (Kays 2005). Sweetpotato is one of the traditional crops that play an important role in addressing food insecurity in most rural households in Africa (Gruneberg et al. 2015). Orange-fleshed sweetpotato varieties have high $\beta$-carotene content (source of provitamin A) and have thus seen increased utilization in food and dietary programs aimed at addressing vitamin A deficiency, a global challenge in Sub-Saharan Africa (Kurabachew 2015). The crop is cultivated year-round in Kenya, producing high yields under marginal conditions. Sweetpotato yields differ from $>25 \mathrm{t} \mathrm{ha}^{-1}$ with high input to $<3 \mathrm{tha}^{-1}$ when grown as a subsistence crop with minimal input (Ling et al. 2010). In Kenya, sweetpotato production is hindered by numerous biotic, abiotic, and social factors (Musembi et al. 2015). Pests and diseases are the greatest limitation, affecting production and reducing yields (Motsa et al. 2015). Viral

Current address for B. W. Wanjala: Kenya Agricultural and Livestock Research Organisation, Nairobi, Kenya.

${ }^{\dagger}$ Corresponding author: J. F. Kreuze; j.kreuze@cgiar.org

Funding: The International Potato Center funded this study through the Sweet Potato Action for Security and Health in Africa project, which was undertaken as part of the CGIAR Research Program on Roots, Tubers and Bananas. This work was also supported by the Bill and Melinda Gates Foundation (grant OPP1019987).

*The $\boldsymbol{e}$-Xtra logo stands for "electronic extra" and indicates that two supplementary figures and two supplementary tables are published online.

The author(s) declare no conflict of interest.

Accepted for publication 5 December 2019.

Copyright (C 2020 The Author(s). This is an open access article distributed under the CC BY 4.0 International license. diseases are the greatest threat to sweetpotato production, causing yield losses of up to $80 \%$ (Gibson and Kreuze 2015).

Sweetpotato is cultivated vegetatively and recycling of vine cuttings leads to a significant decline in root yield and quality as a result of virus accumulation. Sweetpotato virus disease (SPVD), caused by the dual infection of a Potyvirus (Sweet potato feathery mottle virus [SPFMV]) and a Crinivirus (Sweetpotato chlorotic stunt virus [SPCSV]), is the most devastating disease of sweetpotato in East Africa (Gibson et al. 1998; Karyeija et al. 1998). SPFMV is common in sweetpotato-producing regions around the world (Ateka et al. 2004). SPCSV induces synergistic interactions with other sweetpotato viruses such as Sweetpotato mild mottle virus (SPMMV; genus Ipomovirus) (Tairo et al. 2005), Sweetpotato virus G (SPVG; genus Potyvirus) (IsHak et al. 2003), and Cucumber mosaic virus (CMV; genus Cucumovirus) (Cohen and Loebenstein 1991). However, yield decline attributable to these viruses is cultivar dependent and previous studies have reported contradictory findings. For instance, Milgram et al. (1996) and Clark and Hoy (2006) reported that single infection with SPFMV, SPVG, or isolates of Sweetpotato virus 2 (SPV2; syn. Ipomoea vein mosaic virus) did not considerably affect yield. In addition, Gutiérrez et al. (2003) found that SPFMV-infected plants produced better yield than the healthy control. On the contrary, Gibson et al. (1997), Mukasa (2004), Njeru et al. (2004), and Domola et al. (2008) reported yield reductions of up to $46 \%$ as a result of SPFMV.

To date, more than 30 viruses have been characterized as pathogens of sweetpotato, half of them belonging to the families Geminiviridae and Caulimoviridae (Clark et al. 2012). Among them are Sweet potato leaf curl virus (SPLCV) and related viruses belong to the genus Begomovirus in the family Geminiviridae. The sweetpotatoinfecting begomoviruses are highly variable, making their taxonomy, which has been revised over the last five years, problematic. These viruses are distinguished from begomoviruses infecting other crops by their unique phylogenetic lineage, referred to as "Sweepovirus" (Albuquerque et al. 2012; Cuellar et al. 2015; Esterhuizen et al. 2012; Fauquet and Stanley 2003; Wasswa et al. 2011). We will refer to them as such in this article when discussing them in general, rather than as individual isolates. Sweepoviruses are transmitted 
through vegetative propagation and semipersistently by whiteflies (Bemisia tabaci cryptic species complex). They have been isolated from sweetpotato fields in different parts of the world, including the United States, South America, the Middle East, Southeast Asia, and East Africa (Albuquerque et al. 2012; Briddon et al. 2006; Lozano et al. 2009; Luan et al. 2006; Miano et al. 2006; Paprotka et al. 2010; Prasanth and Hegde 2008; Wasswa et al. 2011). Sweepovirus-infected plants may exhibit upward curling and/or rolling of leaves, vein swelling, and vein mottle in young sweetpotato plants. However, symptom remission is observed in mature plants, and most plants eventually become symptomless (Miano et al. 2006). Sweepovirus single viral infections often lack obvious symptoms, making it difficult for growers to recognize. Miano et al. (2006) reported the occurrence of sweepoviruses in an agricultural field station in Kenya. Countrywide surveys conducted in 2011 (Maina 2014; Maina et al. 2017) and in 2016 and 2017 (B. W. Wanjala, unpublished data) confirmed the occurrence of sweepoviruses in the major sweetpotato-growing regions of the country. The presence of sweepovirus inoculum in major sweetpotato-producing areas in Kenya and the continuing expansion of the vector-Bemisia tabaci cryptic species complex (Simmons et al. 2008; Wang et al. 2019) might have contributed to its broad geographic distribution in Kenya.

Despite the lack of characteristic foliar symptoms, sweepoviruses have been reported to cause between 10 and $80 \%$ yield loss for different sweet potato cultivars (Clark and Hoy 2006; Gibson and Kreuze 2015; Ling et al. 2010). Studies have demonstrated that sweepoviruses titers increased when coinfected with SPCSV, leading to increased symptoms in sweetpotatoes under controlled conditions (Cuellar et al. 2015). However, limited knowledge exists on the interaction of sweepoviruses, SPFMV, and SPCSV in sweetpotato under field conditions or their effect on the yield and quality of sweetpotato roots. Therefore, this study aimed to evaluate the effect of Kenyan isolates of SPLCV, SPFMV, and SPCSV alone and in mixed infections of different combinations on sweetpotato root yield of two cultivars that are resistant or susceptible to SPVD.

\section{Materials and Methods}

Sources of healthy planting and detection of sweetpotato viruses. Healthy in vitro plants were obtained from the International Potato Center germplasm collection at the Kenya Plant Health Inspectorate Services Plant Quarantine and Biosecurity Station (KEPHIS-PQBS)

Table 1. Description of treatments (viruses and their combinations) used to evaluate the effect of different viruses on sweetpotato varieties Ejumula and Kakamega

\begin{tabular}{lcll}
\hline Treatment & Plot no. & Cultivar & Treatment description \\
\hline T1 & $15 / 30 / 43$ & & Noninfected \\
T2 & $5 / 17 \times / 40$ & & SPCSV \\
T3 & $16 / 31 / 47$ & & SPFMV \\
T4 & $9 / 27 / 41$ & Ejumula & SPLCV+SPCSV \\
T5 & $3 / 22 / 33$ & & SPLCV+SPFMV \\
T6 & $12 / 23 / 46$ & & SPVD \\
T7 & $14 / 19 / 36$ & & SPLCV+SPVD \\
T8 & $10 / 25 / 44$ & & SPLCV \\
T9 & $4 / 24 y / 39$ & & Noninfected \\
T10 & $11 / 29 / 34$ & & SPCSV \\
T11 & $1 / 20 / 48$ & & SPFMV \\
T12 & $7 / 21 / 35$ & Kakamega & SPLCV+SPCSV \\
T13 & $6 / 32 / 42$ & & SPLCV+SPFMV \\
T14 & $8 / 26 / 38$ & & SPVD \\
T15 & $13 / 28 / 37$ & & SPLCV+SPVD \\
T16 & $2 / 18^{z} / 45$ & & SPLCV \\
\hline
\end{tabular}

${ }^{\mathrm{w}}$ SPCSV $=$ Sweet potato chlorotic stunt virus, SPFMV = Sweet potato feathery mottle virus, $\mathrm{SPLCV}=$ Sweet potato leaf curl virus, and SPVD $=$ Sweet potato virus disease.

$x$ Plot positive for sweepovirus in bulk PCR test at the end of season I.

y Plot positive for SPCSV in bulk PCR at the end of season I.

${ }^{z}$ Plot positive for SPFMV in bulk PCR test at end of season I and SPCSV at the end of season II. in Muguga, Kenya. Plantlets of varieties Kakamega and Ejumula were hardened in insect-proof greenhouses and away from plants that might be infected with viruses. Both cultivars are landraces, are widely adaptable, have good storage root shapes if grown in light soils, have high dry matter content, and have excellent consumer acceptance, especially among children and women (Mwanga et al. 2007). Ejumula is highly susceptible to SPVD, whereas Kakamega shows moderate levels of field resistance to SPVD.

Biological indexing was carried out on I. setosa (indicator plant), which is highly sensitive to most sweetpotato-infecting viruses, as described by Dennien et al. (2013). Vines singly infected with SPFMV, SPFMV, and SPLCV were used as scions to an I. setosa stock seedling following the procedures described in Beetham and Mason (1992) and Dennien et al. (2013). Virus infection treatments (T1 to T16) are described in Table 1. The I. setosa seedling was grown out to 10 nodes (4 to 6 weeks after planting) and grafted with two 2-node scions from the test plant, one from the basal portion of the vine and one from near the apex of the vine. A wedge graft was made at about three nodes above the cotyledonary node and a side veneer graft just below the cotyledonary node. Grafted plants in the pots were covered with plastic bags and placed into large, shallow trays lined with plastic sheeting. The I. setosa indicator plant was allowed to grow. To capture transient symptoms, indicator plants were observed twice weekly until 21 days postgrafting (DPG), then weekly until 42 DPG. The I. setosa was cut back above the graft site and allowed to regrow for an additional 3 to 4 weeks, with continuous observation for symptom development. Symptoms typical of different viruses as illustrated in Clark et al. (2012) and Dennien et al. (2013) were recorded.

A standard nitrocellulose membrane (NCM) enzyme-linked immunosorbent assay (ELISA) was performed using a test kit manufactured by the International Potato Center and as described by Dennien et al. (2013). The kit tests for 10 known sweetpotatoinfecting viruses: C-6, CMV, Sweet potato collusive virus, Sweet potato chlorotic fleck virus, SPCSV, SPFMV, Sweet potato latent virus, SPMMV, Sweet potato mild speckling virus, and SPVG. It is a prerequisite for the test to use material that is first grafted onto $I$. setosa. This increases the virus concentration in the indicator and prevents inhibitors present in sweetpotato sap. There are no antisera available for SPLCV and sweepoviruses were tested by PCR as described by Li et al. (2004), using Sweepovirus-specific primers SPG1 (5'-CCCCKGTGCGWRAATCCAT-3') and SPG2 (5'-ATCCVAAYWTYCAGGGAGCTAA-3'), designed to amplify a 901-bp region encompassing partial AC1 and AC2 open reading frames.

Source of virus inoculum and virus inoculation. Plants singly infected with SPCSV (isolate KE_4) and SPFMV (isolate KE_42) used for graft infection were obtained from KEPHIS-PQBS. The sweepovirus (SPLCV) isolate KE_97 positive plants were collected from different parts of Kenya during surveys. Viruses were confirmed by NCM ELISA screening by PCR as described above for SPLCV. SPCSV and SPFMV were tested with reverse transcription PCR (RT-PCR) as described by Kwak et al. (2014). Furthermore, local isolates of sweepovirus-positive samples were confirmed by Sanger sequencing of the PCR product (GenBank accession MN122257) and confirmed isolate KE_97 was a sweepovirus most closely related to SPLCV. In this work, we will refer to it as SPLCV hereafter. Two-node cuttings were obtained from the VT hardened mother plants of Kakamega and Ejumula and established in a 3-liter pot $(17 \mathrm{~cm}$ in diameter and $20 \mathrm{~cm}$ in height). Media consisted of sterile top forest soil/cow manure/gravel at a ratio of 5:2:1. Plants were grown in the greenhouse at an average temperature of $28^{\circ} \mathrm{C}$ and watered as needed. After 1 month when the plants were approximately $30 \mathrm{~cm}$ tall, 20 plants of both Ejumula and Kakamega were graft-inoculated with a 5 -cm stem scion using the side-veneer procedure (Hartmann et al. 1997). Table 1 shows the different combinations of virus infections with SPLCV, SPFMV, and SPCSV, alone and in possible dual combinations used as treatments in this study. Different treatments were kept in separate insect-proof chambers in the greenhouse to avoid cross-infection. 
Greenhouse multiplication of planting material inoculated with viruses. The different treatments (T1 to T16 described in Table 1) were tested at 3 months after inoculation, by quantitative RT-PCR (qRT-PCR) to confirm the presence/absence of SPFMV, SPCSV, and SPLCV. qRT-PCR reactions were carried out as described by Cuellar et al. (2015). For SPFMV, the coat proteinspecific primers $5^{\prime}$-CGCATAATCGGTTGTTTGGTT T-3' and 5'-TTCCTAAGAGGTTATGTATATTTCTAGTAACATCAG- $3^{\prime}$ and the probe $5^{\prime}$-[6-FAM]-AACGTCTCCACGCAAGAAGAGGATGC[TAMRA]-3' were used. Primers for SPCSV were SPCSV-Uni-E-F (5'-CGGAGTTTATTCCCACYTGTYT-3') and SPCSV-Uni-E-R (5'-GGGCAGCCYCACCAA-3') and the probe was SPCSV-UniE-P (5'-[FAM]-TCTGTCACGGCTACAGGCGACGTG-[TAMRA]-3'), corresponding to the Hsp70h region on RNA2. For SPLCV, the primers 5'-GAGACAGCTATCGTGCC-3' and 5'-GAAACCGGGA CATAGCTTCG-3', and the probe $5^{\prime}$-[6 FAM]-TAC ACT GGG AAT GCT GTC CCA ATT GCT-[TAMRA]-3' were used as described by Ling et al. (2010). Cytochrome oxidase (COX) was used as internal reference gene employing the primers COX-F (5'-CGTCGCATTCCAGATTATCCA-3') and COX-R (5'-CAAC TACGGATATATAAGAGCCAAAACTG- $3^{\prime}$ ) and probe COX-P (5'-[VIC]-TGCTTACGCTGGATGGAATGCCCT-[TAMRA]-3').

Plants that tested positive as expected were rapidly multiplied in seedling trays to generate enough material for field trials. During multiplication, a new sterile scalpel blade was used to cut scions to avoid cross-contamination between treatments. To ensure that adequate planting material was available for field experiments, plants with double/multiple viruses were multiplied in extra trays as a result of slow/stunted growth. The multiplied planting material was further randomly tested by qRT-PCR to confirm the material's infection status before planting in the field.

Field experimental design. Field trials were conducted for two seasons at the Kenya Agricultural and Livestock Research Organization (KALRO) Kiboko Centre in Makueni County, Kenya. The KALRO Kiboko Centre is situated at latitude S $02^{\circ} 12.781^{\prime}$, longitude $\mathrm{E} 037^{\circ} 43.078^{\prime}$, and $931 \mathrm{~m}$ above sea level. The soils were sandy loams for each trial in both seasons. Mean annual rainfall in the region is $50 \mathrm{~mm}$, with a mean monthly maximum temperature of $33^{\circ} \mathrm{C}$. The two seasons of planting were 3 months apart. The first field trial (season I) was established in September 2017 to February 2018, whereas season II was set up in December 2017 to May 2018. Both trials were laid using a randomized complete block design with three replicates for the 16 treatments. The land was plowed and harrowed and ridges prepared by hand at the two sites before planting. Each replicate (plot) comprised 40 plants at inter- and intrarow spacing of 1 and $0.3 \mathrm{~m}$, respectively. Vine cuttings were 4 weeks old (approximately $30 \mathrm{~cm}$ long) at the time of planting. Plants were watered immediately after planting and watered by overhead irrigation for $3 \mathrm{~h}$ at night every 4 days. Weeding was done manually using hand hoes twice a month in the first 2 months and once thereafter until the crop was harvested. Two rows of finger millet were planted around each plot to reduce potential spread of viruses between plots by insect vectors. To monitor whitefly abundance, a yellow sticky card trap $\left(26 \mathrm{~cm}^{2}\right)$ was placed horizontally at canopy height at the center of each plot. These traps were replaced after every 2 months. To minimize further spread of viruses between plots; plants were sprayed fortnightly by alternating systemic and contact insecticide as described by the manufacturer on the container product label.

Evaluation of SPLCV, SPFMV, and SPCSV under field conditions. Disease symptom evaluation was conducted at 30 , 90, and 120 days after planting (DAP) as described by Hahn et al. (1981). A severity score of 1 to 5 was used: 1 indicates plants showing no symptoms; 2 indicates virus symptoms just starting to appear, and this can be as mild chlorotic spots on the older leaves or mild vein clearing or mild purpling at the leaf margin of mature leaf; 3 indicates that the symptoms in 2 are enlarged and becoming more visible; 4 indicates infected plants showing severe disease symptoms, including leaf purpling, leaf chlorosis, and leaf shape that is starting to get distorted; and 5 indicates infected plants showing very severe virus disease symptoms, including total distortion in leaf shape, stunted growth, mosaic, leaf chlorosis, and sometimes complete death of an infected plant. At the end of both growing seasons, cross-contamination between plots was evaluated by testing with RT-PCR. Three leaves (third, fifth, and seventh) were collected from 10 plants in the inner middle rows, placed between filter papers, and put in a plastic zip-top bag with silica gel. The silica gel was changed several times when the color changed from blue to pink to ensure that the leaves were well desiccated. Samples were pooled into one sample per plot and tested for SPCSV, SPFMV (RT-PCR), and SPLCV (PCR) as described above.

Root yield assessment. Plants were harvested at 150 DAP, on 15 February and 15 May 2018, respectively. Storage roots were graded as marketable (good-quality roots of 100 to $1,200 \mathrm{~g}$ ) or unmarketable $(<100 \mathrm{~g})$. Data on the following 16 parameters were collected during the experiment: disease severity, main branches length (in centimeters), vine vigor (rate of shoot growth, vine strength, diameter, and internode length; Gruneberg et al. 2010), weight of vines per plot (in kilograms), number of roots per plant, number of marketable storage roots, number of nonmarketable storage roots, weight of marketable storage roots (in kilograms), number of nonmarketable storage roots (in kilograms), total root yield (in tons per hectare), marketable root yield (in tons per hectare), foliage yield (in tons per hectare), percentage of commercial root yield, ratio of root length/diameter, root dry matter content (in percent), and harvest index (HI).

Statistical analysis. The GLM procedure in SAS software (version 9.1; SAS Institute Inc., Cary, NC) was used for analysis of variance. The two-season data were analyzed and are presented separately and as combined means for the two seasons. Separation of means was achieved by Tukey's studentized range test. In addition, analysis of variance was used to test for differences between treatments and treatment means were separated by Fisher's protected $t$ test least significant difference using GenStat. Furthermore, principal component analysis (PCA) and Pearson correlation coefficients showing pairwise associations of traits for yield and yield-contributing characteristics were generated by XLSTAT to show the relationship between key parameters measured and treatments.

\section{Results}

Symptom expression and virus detection in single or mixed infection by SPFMV, SPCSV, and SPLCV under field conditions. Analysis of variance for disease severity taken at 90 DAP showed a significant $(F p r .<0.001)$ interaction between virus treatments for both Ejumula and Kakamega for the two seasons as shown in Table 2 and Figure 1. Ejumula was more severely affected than Kakamega for the different virus treatments. The uninfected control treatments for Ejumula and Kakamega did not display symptoms compared with the virus-infected treatments (Figs. 2B and 3B). Disease severity scores in both seasons differed among treatments. Plants singly infected with SPLCV produced mild symptoms in the two varieties used in this study (Figs. 2A and 3A). These plants exhibited slight rugosity and upward curling or rolling of leaves (Figs. 2A and 3A). Disease severity attributable to single infections of SPCSV and SPFMV was significant in both cultivars and both seasons. The uninfected controls were symptomless (Figs. 2B and 3B). Purple rings characterized the symptom expression attributable to SPFMV (Figs. 2C and 3C), whereas SPCSV displayed purpling of the interveinal areas on older leaves (Figs. 2E and 3E). The combination of SPCSV+SPLCV had more pronounced severity in both seasons on Ejumula, showing chlorotic spots and rugosity (Fig. 2D); however, it was less severe for Kakamega, showing purpling of older leaves and upward curling (Fig. 3D). SPVD and SPVD+SPLCV were the most severe for both seasons on both sweetpotato varieties. These included vein chlorosis, purple spots, mosaic, leaf narrowing, deformation, and stunted growth (Figs. $2 \mathrm{~F}$ and $3 \mathrm{~F}$ ). It is worth noting that symptom severity declined at 120 DAP in both varieties in both seasons. RT-PCR/PCR tests performed on bulk samples at the end of the experiment and just before harvest indicated that the following plots were contaminated with viruses with which they had not been preinoculated: Ejumula, plot 17 (contaminated by SPLCV); 
Kakamega, plot 24 (contaminated by SPCSV); and Kakamega, plot 18 (contaminated by SPFMV in season I and by SPCSV in season II) (Table 1). Because tests were done on bulks, we were unable to determine the extent of the contamination. However, considering the overall low level of cross-plot contamination observed in bulk sample testing, we assumed that it was limited to no more than one or two plants/bulk. We could not ascertain the mechanisms of infection for the specific plots, time of infection, and whether the infection contributed to yield loss. However, because there was no statistically significant difference with the other replicates for the same treatment and symptoms corresponding to those of the contaminating viruses were also not obvious in these plots, we assumed that they responded to few and late season infections that had minimal impact on plant performance and this was thus not considered during analysis. Because no wild Ipomoea or sweetpotato fields were present at or near the field trial plots, the source of virus contamination was most likely from adjacent plots.

Effects of virus infection on total root yield. Season I resulted in a greater yield and storage root number (Supplementary Table S1) than season II, despite symptoms being generally milder (Supplementary Table S2) in the latter. Significant differences $(F p r .<$ 0.001 ) were detected among treatments for root yield-related traits (number of roots per plant, number of marketable storage roots, total storage root yield [in tons per hectare], and ratio of root length/ diameter) (Table 2). The total root yield differed significantly for different treatments, varieties, and seasons (Table 2). The uninfected control treatments for Ejumula and Kakamega gave higher storage root yields (in tons per hectare) compared with the different virus treatments as shown in Figure 4. Kakamega singly infected with SPLCV or all three viruses had a significant yield reduction of 47 or $35 \%$, respectively. Kakamega infected with other single and/or multiple viruses gave lesser yield reductions ranging from 6 (SPFMV or SPFMV+SPLCV) to $29 \%$ (combinations with SPCSV) but these were not significantly different from the control (Table 2). In contrast, there was no yield reduction for Ejumula infected with SPLCV alone. However, Ejumula infected with all other combinations gave significant yield reductions ranging from 25 to $44 \%$ compared with the uninfected control (Table 2). Significant differences $(F p r .<$ 0.001 ) were observed in the ratio of root length/diameter and the number of nonmarketable roots for some of the different virus

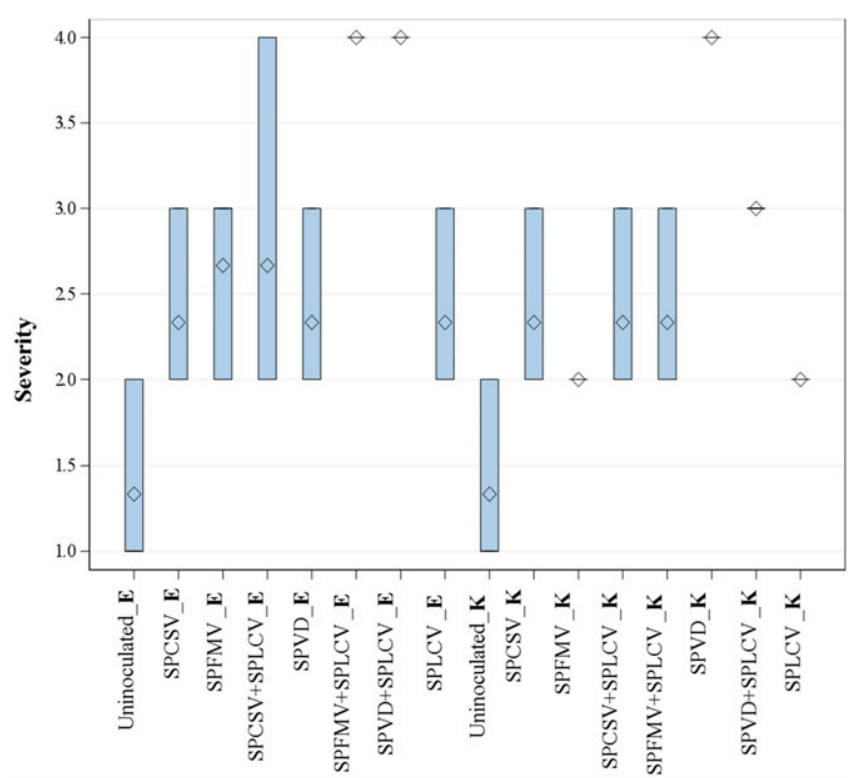

Fig. 1. Boxplot for disease severity inoculated with different viruses for combined means for seasons I and II, expressed as the varying level of disease symptoms. A severity score of 1 depicts mild symptom expression, whereas a score of 5 indicates pronounced expression. All of the treatments for Ejumula and Kakamega are abbreviated as $\mathrm{E}$ and $\mathrm{K}$, respectively. SPCSV = Sweet potato chlorotic stunt virus, SPFMV = Sweet potato feathery mottle virus, SPLCV $=$ Sweet potato leaf curl virus, and SPVD = sweet potato virus disease.

Table 2. Yield parameters for sweetpotato inoculated with Sweet potato leaf curl virus (SPLCV), Sweet potato feathery mottle virus (SPFMV), sweet potato virus disease (SPVD), and Sweet potato chlorotic stunt virus (SPCSV), alone and in all possible combinations on varieties Ejumula and Kakamega for seasons I and II combined

\begin{tabular}{|c|c|c|c|c|c|c|}
\hline \multirow[b]{2}{*}{ Treatment $^{\mathrm{z}}$} & \multicolumn{5}{|c|}{ Yield parameter, seasons I and II } & \multirow[b]{2}{*}{$\begin{array}{c}\text { Yield reduction } \\
(\%)\end{array}$} \\
\hline & $\begin{array}{c}\text { Severity } \\
(1-5)\end{array}$ & $\underset{(n)}{\text { Roots per plant }}$ & $\begin{array}{l}\text { Marketable storage roots } \\
(n)\end{array}$ & $\begin{array}{c}\text { Ratio of root length/ } \\
\text { diameter }\end{array}$ & 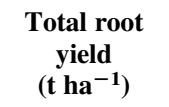 & \\
\hline Negative Cntl_Ejumula & $1.33 \mathrm{e}$ & $6.00 \mathrm{abcd}$ & 29.33 & $3.57 \mathrm{bcd}$ & $15.92 \mathrm{abc}$ & Control \\
\hline SPCSV_Ejumula & $2.33 \mathrm{~cd}$ & 4.82 efgh & 24.17 & $4.81 \mathrm{a}$ & $10.11 \mathrm{e}$ & 38 \\
\hline SPFMV_Ejumula & $2.67 \mathrm{bc}$ & 5.02 defgh & 25.17 & $3.84 \mathrm{~b}$ & $9.14 \mathrm{e}$ & 44 \\
\hline SPLCV+SPCSV_Ejumula & $2.67 \mathrm{bc}$ & 5.28 bcdef & 21.00 & $3.37 \mathrm{bcd}$ & 11.56 bcde & 25 \\
\hline $\begin{array}{l}\text { Sweepo +SPFMV } \\
\text { Ejumula }\end{array}$ & $2.17 \mathrm{~cd}$ & 5.25 bcdef & 22.67 & $3.82 \mathrm{bc}$ & $9.17 \mathrm{e}$ & 44 \\
\hline SPVD_Ejumula & $3.67 \mathrm{a}$ & $4.43 \mathrm{fgh}$ & 22.17 & $3.63 \mathrm{bcd}$ & $11.25 \mathrm{cde}$ & 32 \\
\hline SPLCV +SPVD_Ejumula & $3.67 \mathrm{a}$ & $4.03 \mathrm{~h}$ & 21.17 & $3.67 \mathrm{bcd}$ & $9.11 \mathrm{e}$ & 44 \\
\hline SPLCV_Ejumula & $2.17 \mathrm{~cd}$ & 5.07 cdefg & 26.50 & $3.37 \mathrm{bcd}$ & $15.64 \mathrm{abcd}$ & 0 \\
\hline Negative Cntl_Kakamega & $1.17 \mathrm{e}$ & $6.17 \mathrm{ab}$ & 22.83 & $3.23 \mathrm{~d}$ & $16.50 \mathrm{a}$ & Control \\
\hline SPCSV_Kakamega & $2.33 \mathrm{~cd}$ & 5.63 abcde & 19.33 & $3.43 \mathrm{bcd}$ & 13.28 abcde & 24 \\
\hline SPFMV_Kakamega & $2.00 \mathrm{~d}$ & $6.15 \mathrm{ab}$ & 22.67 & $3.86 \mathrm{~b}$ & 15.78 abcd & 6 \\
\hline $\begin{array}{l}\text { SPLCV +SPCSV } \\
\text { Kakamega }\end{array}$ & $2.17 \mathrm{~cd}$ & 5.75 abcde & 19.17 & $3.11 \mathrm{~d}$ & 12.22 abcde & 29 \\
\hline $\begin{array}{l}\text { SPLCV +SPFMV_ } \\
\text { Kakamega }\end{array}$ & $2.17 \mathrm{~cd}$ & $6.00 \mathrm{abcd}$ & 19.50 & $3.53 \mathrm{bcd}$ & $16.17 \mathrm{ab}$ & 6 \\
\hline SPVD_Kakamega & $3.83 \mathrm{a}$ & $6.07 \mathrm{abc}$ & 13.67 & $3.86 \mathrm{~b}$ & 12.75 abcde & 24 \\
\hline $\begin{array}{l}\text { SPLCV }+\mathrm{SPVD}_{-} \\
\text {Kakamega }\end{array}$ & $3.00 \mathrm{~b}$ & $6.57 \mathrm{a}$ & 16.83 & $3.25 \mathrm{~cd}$ & $10.94 \mathrm{de}$ & 35 \\
\hline SPLCV_Kakamega & $2.00 \mathrm{~d}$ & $4.27 \mathrm{gh}$ & 17.33 & $3.59 \mathrm{bcd}$ & $9.08 \mathrm{e}$ & 47 \\
\hline$F p r$ & $<0.001$ & $<0.001$ & 0.053 & $<0.001$ & $<0.001$ & \\
\hline LSD $5 \%$ & 0.538 & 1 & 8.161 & 0.575 & 4.9 & \\
\hline $\mathrm{CV} \%$ & 8.1 & 5.8 & 8.2 & 1.6 & 9 & \\
\hline
\end{tabular}

y Values shown are means for the 16 treatments. Values within the same column followed by identical letters are not statistically different (analysis of variance,

Fisher's protected least significance difference [LSD] test).

${ }^{\mathrm{z}} \mathrm{Cntl}=$ control and $\mathrm{CV}=$ coefficient of variation . 
treatments. Kakamega consistently produced more fibrous roots (and less tubers) compared with the uninfected control treatment when singly infected with SPLCV or in combination with SPCSV (Supplementary Fig. S1) or SPFMV.

Yield component trait correlation with total storage root yield. The evaluated yield component traits showed significant correlations with total storage root yield. As shown in Table 3, total storage root yield (in tons per hectare) had a strong significant positive association with vine vigor (0.654), marketable storage root yield (in tons per hectare) (0.910), percentage of commercial roots $(0.525)$, and
$\mathrm{HI}$ (0.536). Foliage yield (in tons per hectare) (0.485) and the number of roots per plant $(0.338)$ recorded a relatively strong but nonsignificant positive association. In contrast, a negative association was observed between total storage root yield and symptom severity $(-0.605)$. In addition, the ratio of root length/diameter $(-0.387)$ and the number of nonmarketable roots $(-0.337)$ were negatively correlated with symptom severity, although this was not significant. The results of the correlation biplot (Fig. 5) support an association of significant correlated traits for yield and yield-contributing characteristics. Sweetpotato yield parameters varied substantially under the
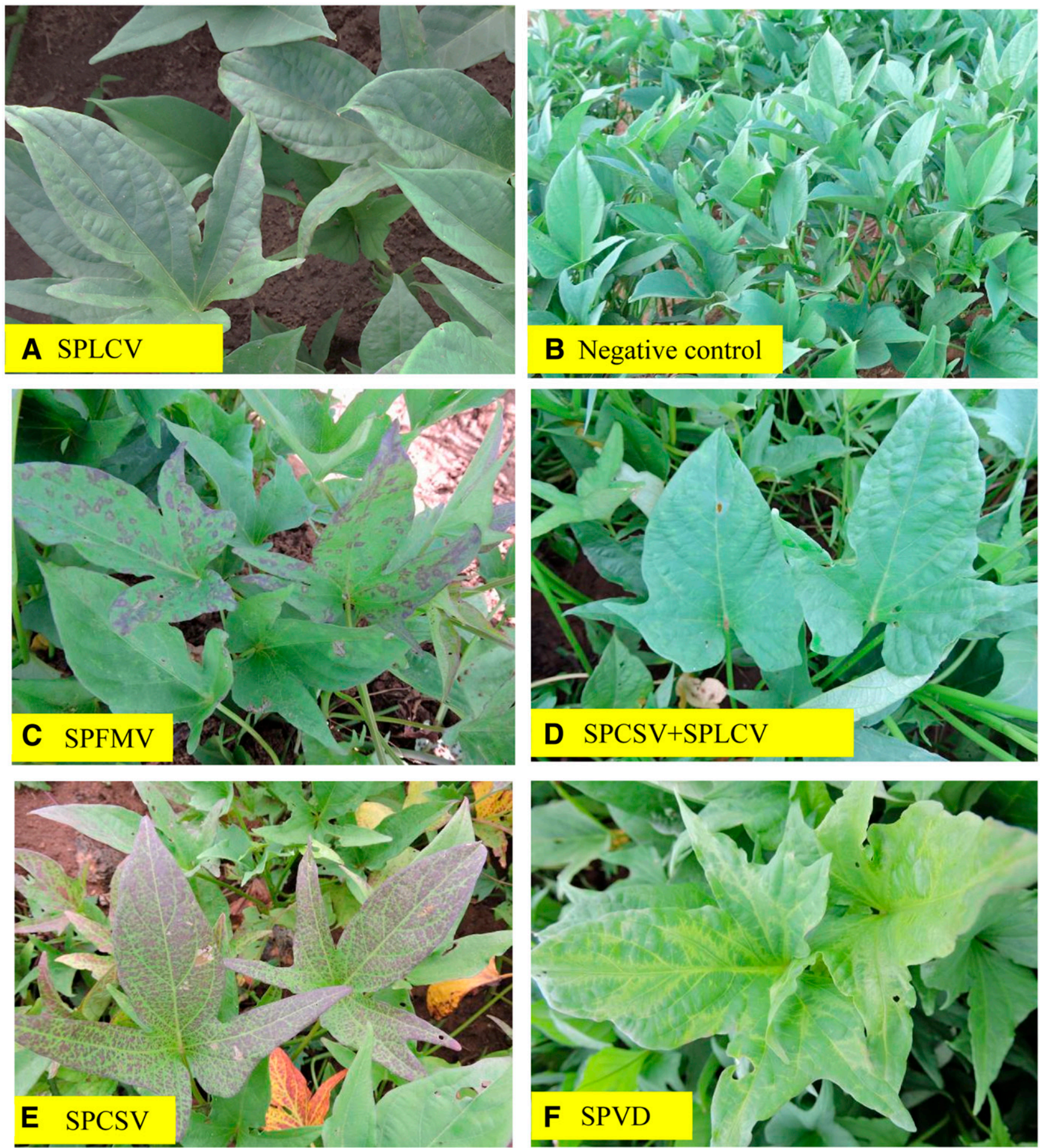

Fig. 2. Symptom expression attributable to single or mixed infection on Ejumula by Sweet potato leaf curl virus (SPLCV; sweepovirus), Sweet potato feathery mottle virus (SPFMV) and Sweet potato chlorotic stunt virus (SPCSV) under field conditions. A, Rugosity attributable to SPLCV. B, Uninfected. C, Purple spot attributable to SPFMV. D, Rugosity and chlorotic spots owing to SPCSV+Begomo. E, Purpling of older leaves as a result of SPCSV. F, Vein clearing, chlorosis, and leaf reduction/deformation as a result of sweet potato virus disease (SPVD). 
virus treatments and for both varieties. The following were most important to distinguish the virus treatments: total storage root yield (in tons per hectare), vine vigor, marketable storage root yield (in tons per hectare), percentage of commercial roots, HI, foliage yield (in tons per hectare), and number of roots per plant displayed furthest away from the center. The PCA further showed the association of variables (yield parameters) and virus treatments with PCA factor scores in terms of response for the treatments. The uninoculated treatments for Ejumula and Kakamega had the highest storage root yield (in tons per hectare) (Table 2). In contrast, the SPVD+SPLCV treatments for Ejumula and Kakamega had the highest severity scores (Table 2).

\section{Discussion}

Sweepoviruses have increasingly been reported from throughout the world. Despite showing few symptoms, more studies are reporting
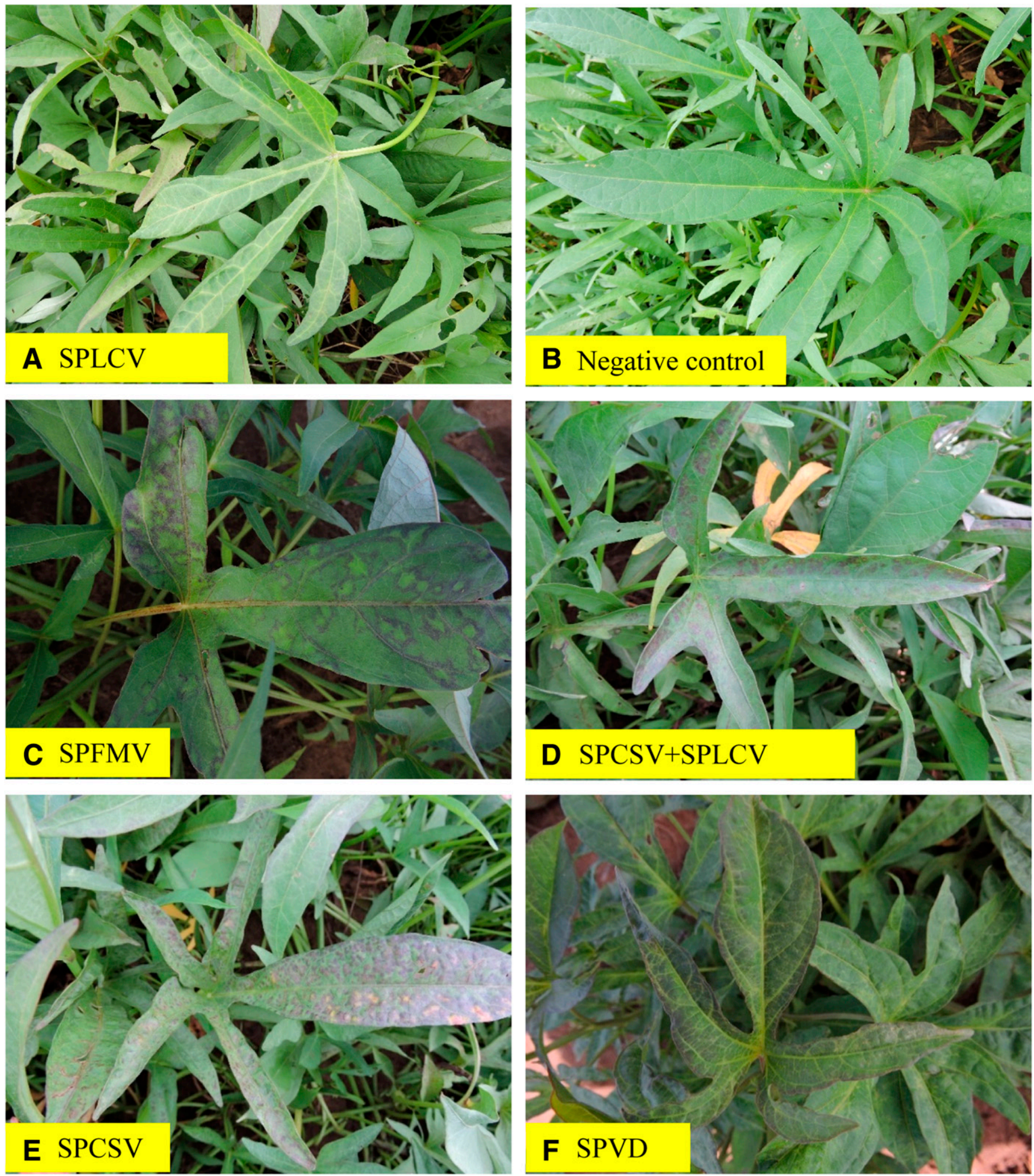

Fig. 3. Symptom expression attributable to single or mixed infection on Kakamega by Sweet potato leaf curl virus (SPLCV), Sweet potato feathery mottle virus (SPFMV), and Sweet potato chlorotic stunt virus (SPCSV) under field conditions. A, Chlorosis and vein clearing to SPLCV. B, Uninfected. C, Purple spot attributable to SPFMV. D, Purpling and roll up attributable to SPCSV+Begomo. E, The bottom left shows purpling of older leaves attributable to SPCSV. F, Vein clearing, chlorosis, and leaf reduction/deformation as a result of sweet potato virus disease (SPVD). 
sweepoviruses to have a varying but significant impact on root yields (Ling et al. 2010). However, until only very recently (Mulabisana et al. 2019), there had been no reports on their impact on African sweetpotato varieties, and this is the first report of their effect on East African varieties developed from local landraces. We show that SPLCV-infected plants produced mild symptoms in both varieties evaluated in this study, with the symptoms dissipating as the plants matured. This expands on earlier investigations that reported lack of any symptoms in SPLCV-infected plants (Ling et al. 2010; Lotrakul et al. 2003). Similarly, Mulabisana et al. (2019) recently reported mild to no symptoms depending on varieties infected with two different sweepoviruses, whereas Cuellar et al. (2015) demonstrated the effect of virus isolates and plant age on symptom expressions and virus titers. Thus, sweepovirus symptomatology can vary depending on

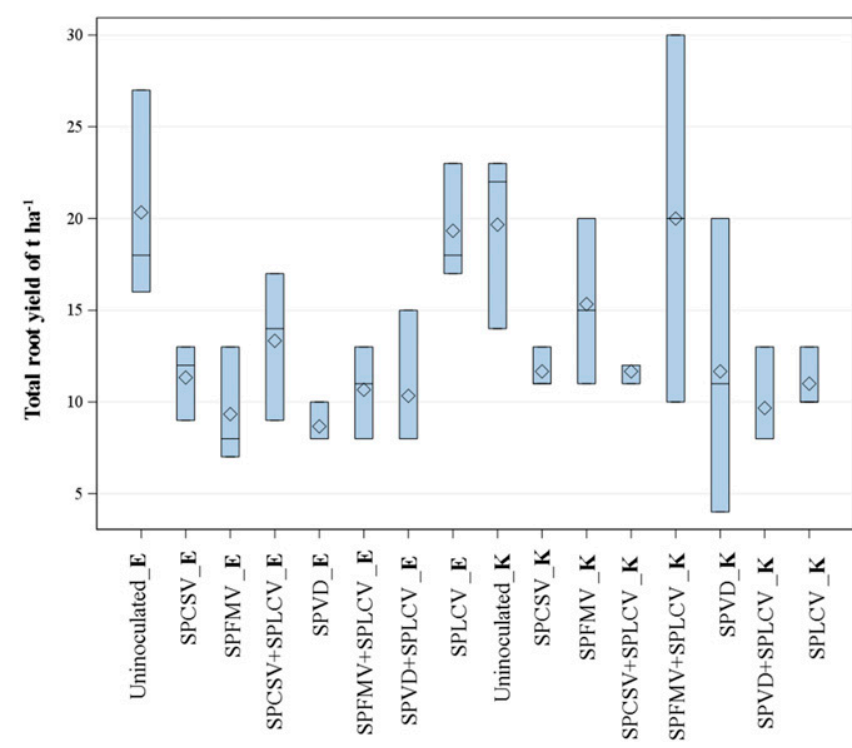

Fig. 4. Box plot root yield in tons per hectare for treatments inoculated with different viruses. All of the treatments for Ejumula and Kakamega are abbreviated as $\mathrm{E}$ and $\mathrm{K}$, respectively. SPCSV $=$ Sweet potato chlorotic stunt virus, SPFMV $=$ Sweet potato feathery mottle virus, SPLCV $=$ Sweet potato leaf curl virus, and SPVD = sweet potato virus disease. cultivar, virus strain, and plant age but invariably is mild and often absent.

Results from our trials show that differences in root yield from SPLCV-infected sweetpotato were not significantly different from the uninfected treatments for Ejumula for the two seasons. On the contrary, Kakamega had a significant yield reduction following single infection with SPLCV. This illustrates varietal differences in response to sweepovirus infection, as found by previous studies reporting yield reductions between 10 and $94 \%$ between different varieties (Clark and Hoy 2006; Ling et al. 2010; Mulabisana et al. 2019). Notable findings from this study compared with previous studies were the clear differences in the levels of susceptibility to SPLCV between the two cultivars used in our experiments. Whereas Ejumula is relatively susceptible to SPFMV and SPCSV and appeared insensitive to SPLCV, Kakamega is more resistant to SPFMV and SPCSV and highly sensitive to SPLCV. This result thus highlights the fact that resistance to SPVD and SPLCV (and likely other sweepoviruses) is not necessarily linked. Furthermore, yield losses and symptoms caused by coinfections of SPLCV with SPFMV, SPCSV, or both viruses were not significantly different from those caused by the single infection of the most severe virus in the combination, suggesting a lack of synergism between these viruses and their limited additive effect on yield losses.

SPCSV is considered the most damaging virus of sweetpotato because of its ability to induce synergistic outcomes when present in mixed infections with several other viruses (Kim et al. 2017), as shown for its coinfection with SPFMV, causing SPVD (Gibson and Kreuze 2015). By itself, SPCSV may cause mild to severe symptoms of yellowing or reddening of older leaves, which can often be confused with nutritional deficiencies (Untiveros et al. 2007). Corresponding to the level of resistance of the varieties, single infection by SPCSV induced pronounced symptoms in Ejumula (considered susceptible) and produced milder symptoms in Kakamega (considered tolerant) and led to yield losses of 38 and $24 \%$ on average, respectively, in both varieties over both seasons. Coinfection of SPCSV with SPFMV increased symptom severity and yield loss in both cultivars. In Ejumula, yield losses were significantly different between plants infected by SPFMV, SPCSV, or both viruses; in Kakamega, the yield losses between SPCSV, SPFMV, and coinfected plants were identical. This contrasts with most previous reports, in which more severe yield reductions (from 60 to $95 \%$ ) were found when plants were coinfected by SPCSV and SPFMV (Gibson et al. 1998;

Table 3. Pearson correlation coefficients showing pairwise associations for yield and yield-contributing characteristics of sweetpotato varieties Ejumula and Kakamega using virus tested and virus infected (with Sweet potato leaf curl virus [SPLCV], Sweet potato feathery mottle virus [SPFMV], sweet potato virus disease [SPVD], and Sweet potato chlorotic stunt virus [SPCSV], alone and in all possible dual combinations), evaluated for two seasons in Kenya ${ }^{y}$

\begin{tabular}{|c|c|c|c|c|c|c|c|c|c|c|}
\hline Variable $^{\mathrm{z}}$ & Severity & $\begin{array}{l}\text { Vine } \\
\text { vigor }\end{array}$ & $\begin{array}{c}\text { Ratio of root length/ } \\
\text { diameter }\end{array}$ & $\begin{array}{c}\text { Foliage } \\
\text { yield } \\
\left(\mathrm{t} \mathrm{ha}^{-1}\right)\end{array}$ & $\begin{array}{c}\text { Roots per } \\
\text { plant } \\
(n)\end{array}$ & $\begin{array}{c}\text { Total root } \\
\text { yield } \\
(\mathbf{t ~ h a} \\
-1)\end{array}$ & $\begin{array}{c}\text { Marketable } \\
\text { roots } \\
\left(\mathbf{t ~ h a}^{-1}\right)\end{array}$ & $\begin{array}{c}\text { Commercial } \\
\text { roots } \\
(\%)\end{array}$ & $\begin{array}{c}\text { Nonmarketable } \\
\text { roots } \\
(n)\end{array}$ & $\begin{array}{c}\text { Harvest } \\
\text { index } \\
\text { (HI) }\end{array}$ \\
\hline Severity & 1 & & & & & & & & & \\
\hline Vine_vigor & -0.925 & 1 & & & & & & & & \\
\hline $\begin{array}{l}\text { Ratio___ } \\
\text { Root_L_D }\end{array}$ & 0.204 & -0.189 & 1 & & & & & & & \\
\hline $\begin{array}{l}\text { Foliage_Yield } \\
\text { Ton/Ha }\end{array}$ & -0.485 & 0.364 & 0.180 & 1 & & & & & & \\
\hline $\begin{array}{l}\text { No_roots_ } \\
\text { plant }\end{array}$ & 0.137 & 0.192 & 0.188 & 0.319 & 1 & & & & & \\
\hline $\begin{array}{l}\text { Total_Yield } \\
\text { Ton/Ha }\end{array}$ & -0.605 & 0.654 & -0.387 & 0.485 & 0.338 & 1 & & & & \\
\hline $\begin{array}{l}\text { Mkt_Roots } \\
\text { Ton/Ha }\end{array}$ & -0.599 & 0.605 & -0.482 & 0.547 & 0.283 & 0.910 & 1 & & & \\
\hline $\begin{array}{l}\% \text { Comm_ } \\
\text { Roots }\end{array}$ & -0.590 & 0.490 & -0.653 & 0.285 & -0.283 & 0.528 & 0.678 & 1 & & \\
\hline $\begin{array}{l}\text { No_Non_ } \\
\text { Mkt_Roots }\end{array}$ & 0.296 & -0.428 & 0.371 & -0.193 & 0.153 & -0.337 & -0.420 & -0.426 & 1 & \\
\hline $\mathrm{HI}$ & -0.313 & 0.494 & -0.629 & -0.325 & 0.069 & 0.536 & 0.528 & 0.405 & -0.333 & 1 \\
\hline
\end{tabular}

$\mathrm{y}$ Values in bold are different from 0 with a significance level alpha $=0.05$. A negative value denotes a negative correlation, whereas a positive value denotes a positive correlation of yield and yield-contributing characteristics.

${ }^{\mathrm{z}} \mathrm{L} \_\mathrm{D}=$ length/diameter, $\mathrm{No}=$ number, $\mathrm{Mkt}=$ marketable, and Comm $=$ commercial. 
Gutiérrez et al. 2003; Milgram et al. 1996). This disparity may be attributable to differences between virus strains and/or varieties used in the different studies. Furthermore, the infection of SPLCV in combination with SPFMV and SPCSV led to slightly higher significant $(F p r .<0.001)$ yield reductions compared with SPFMV and SPCSV alone in both cultivars.

Gutiérrez et al. (2003) and Tugume et al. (2013) reported that SPFMV-infected sweetpotato varieties Jonathan and Costanero did not show foliage symptoms under field conditions. Nevertheless, typical symptoms associated with SPFMV were observed in the current study and also by Mulabisana et al. (2019). However, as with SPLCV, a reduction of symptoms was observed in SPFMVinfected plants as they matured and most plants became symptomless after 16 weeks postplanting. This phenomenon was reviewed by Gibson and Kreuze (2015) who reported that popular East African sweetpotato cultivars appear to sustain their long-term survival by reverting to symptomless infection and even becoming virus free in some instances. In our trials, SPFMV by itself had a significant yield impact on Ejumula, whereas Kakamega was not affected, which is in concordance with their level of resistance. Previous investigations have also presented contradictory conclusions regarding yield reductions by single SPFMV infections. Milgram et al. (1996), Clark and Hoy (2006), and Gutiérrez et al. (2003) noted that single infection with SPFMV did not greatly affect yield. On the other hand, yield reductions of up to $46 \%$ attributable to SPFMV were reported in other studies (Domola et al. 2008; Gibson et al. 1997; Mukasa 2004; Njeru et al. 2004). Mulabisana et al. (2019) reported reductions of 27 to $92 \%$ owing to single infection with
SPFMV across 12 different cultivars in field trials in South Africa with notable between-season effects. Thus, as in the case of sweepoviruses and SPCSV, the impact of SPFMV single infection on yield seem to be highly cultivar specific and may be higher than previously assumed globally. Gibson and Kreuze (2015) comprehensively documented previous work on yield reductions reported by treatments and cultivars.

Previous investigations have documented that both yield and quality of storage roots are sensitive to environmental variations: from year to year, field to field, and even within the same field (Bryan et al. 2003; Collins et al. 1987; Ngeve and Bouwkamp 1993). Yield variation among treatments and seasons could be attributed to climatic factors such as rainfall and temperature (Roitsch et al. 2003). In season II, we experienced a 4-fold increase in rainfall in the study area compared with season I, but there was no significant difference in temperature (Supplementary Fig. S2). Sweetpotato is sensitive to waterlogging and too much water, specifically early in the growing season, could have led to a lower yield in season II than in the first season.

The PCA biplot supports an association of significant correlated traits for yield and helps identify yield-contributing characteristics. Furthermore, it shows the relationship between variables (yield and yield-contributing traits) and observation (virus treatments) scores, with PCA factor scores in terms of response for the treatments. For instance, uninoculated treatments for Ejumula and Kakamega had the highest storage root yield (in tons per hectare). In contrast, treatments inoculated with SPVD+SPLCV for Ejumula and Kakamega were associated with the highest severity scores and low root yield.

\section{CORRELATION BIPLOT (AXES F1 AND F2: 67.08\%)}

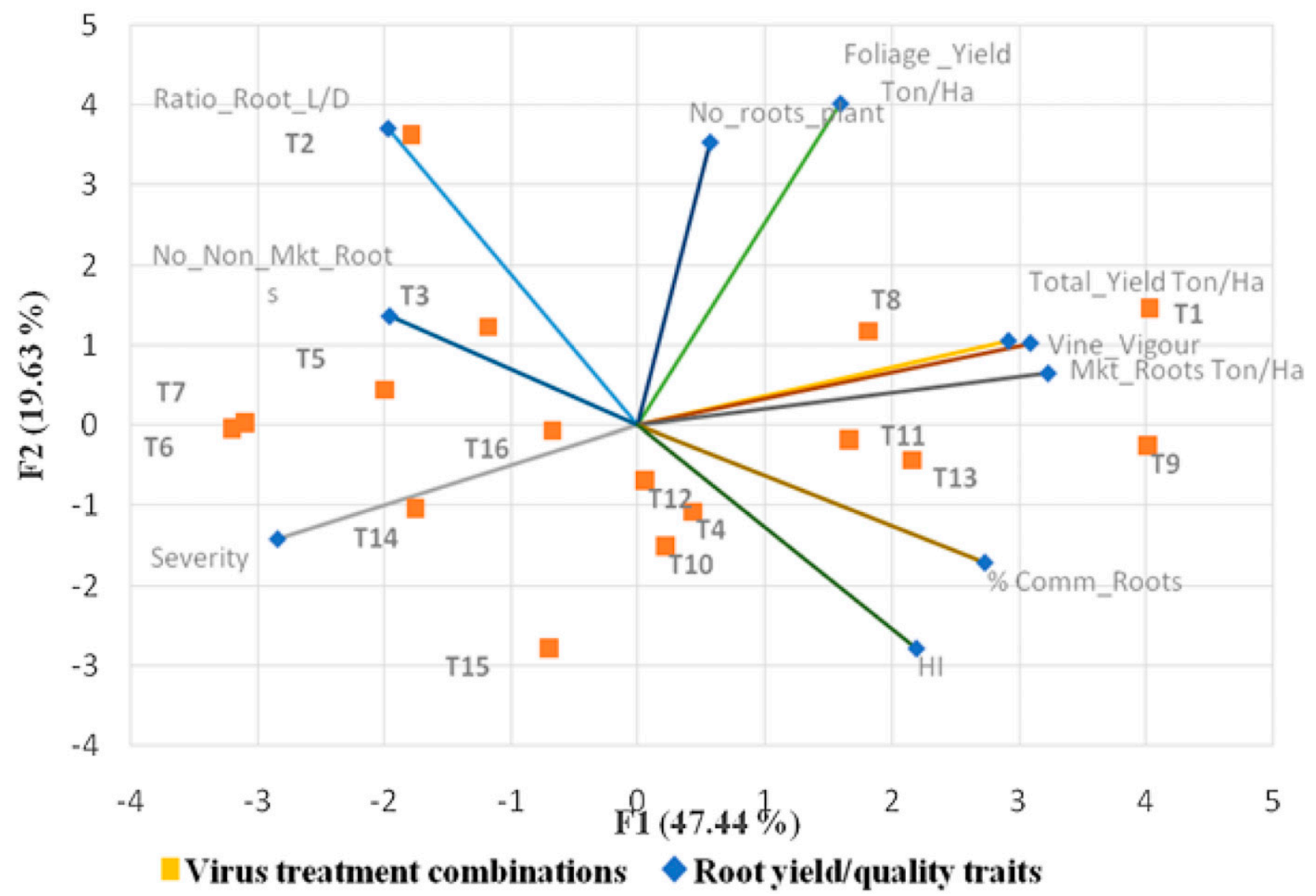

Fig. 5. Correlation biplot representing root yield/quality trait observations and virus treatment variables. Narrow angles depict positively related observations, right angles depict unrelated observations, and obtuse (wide) angles depict negatively related observations. See Table 1 for treatment descriptions. L/D $=$ length/diameter, No $=$ number, Mkt $=$ marketable, Comm = commercial, and $\mathrm{HI}=$ harvest index. 
Understanding the interrelationships among various yield and yieldcontributing characteristics is important and can be utilized by breeders when evaluating for virus-tolerant varieties during selection.

In both varieties, the highest negative and significant association existed between total storage root yield and disease severity. Gurmu et al. (2014) described a negative correlation between virus symptoms and root yield, which is consistent with our results. SPVD is a damaging disease complex of sweetpotato and the negative correlation observed between fresh root yield and disease severity was expected. In addition, the ratio of root length/diameter and the number of nonmarketable roots were negatively corelated to root yield, although this was not significant. These findings corroborate those of Bryan et al. (2003) who noted that virus-infected planting material produced storage roots with a high length/diameter ratio, culminating in lower total yield and poor root quality.

Conclusions. Our study confirmed the relative susceptibility of Ejumula to SPVD and revealed that it expressed equal sensitivity to SPFMV and SPCSV. The relatively SPVD-tolerant phenotype of Kakamega was expressed as reduced symptoms and absence of yield penalties upon SPFMV infection and reduced symptoms but levels of yield losses upon SPCSV infection that were comparable to those of Ejumula. In contrast to other studies and despite the obvious enhancement of symptoms in SPVD-affected plants of both cultivars, we found no evidence of synergistic yield reductions compared with single infections, which suggests that symptoms may not always be an adequate indicator for the effect on yield. This was also clearly the case for SPLCV infection. Considering the widespread presence of begomoviruses globally and also in Africa, this suggests that breeders need to take into account these viruses when selecting for SPVD resistance, as they may inadvertently be selecting for sweepovirus susceptibility. Nevertheless, even in Kakamega, SPLCV infections induced only mild symptoms that disappeared over time, making such plants difficult to identify by farmers, seed producers, and breeders alike to implement any control methods. Thus, adequate diagnostic tests are needed to support these efforts. No effective antisera are available for sweepoviruses and the PCR tests used in this study are too cumbersome for routine implementation in breeding programs or seed certification systems in East Africa. An effort into developing easier-to-use molecular diagnostics for sweepoviruses based on isothermal amplifications systems is recommended to support these efforts.

Although only one sweepovirus isolate was used in this study, we know from previous studies that this group of viruses is highly variable and that different isolates differ in their ability to induce symptoms in sweetpotatoes and indicator plants and accumulate at different titers (Cuellar et al. 2015). Important questions that remain to be answered are whether different isolates/species differ in their impact on sweetpotato root yield, whether this can be correlated to any particular characteristics other than symptoms (e.g., virus titers), and whether resistance of sweetpotatoes to one of them is correlated with resistance to other virus isolates. Thus, immediately relevant research topics include evaluating the extent of sweepovirus infections as well as the virus variability in farmers' fields in Kenya and Africa in general and the susceptibility of current sweetpotato varieties to these viruses, particularly those selected for resistance to the more visible SPVD.

\section{Acknowledgments}

We thank the KEPHIS-PQBS in Muguga, Kenya, for laboratory and screenhouse facilities where diagnostic assays and propagation of planting material was conducted. We also thank the KALRO director general for granting study leave to B. W. Wanjala. We greatly appreciate provision of land for undertaking field work. Finally, we thank Dr. Daniel Pande for reviewing the draft manuscript. This work is part of a Ph.D. research study by B. W. Wanjala.

\section{Literature Cited}

Albuquerque, L. C., Inoue-Nagata, A. K., Pinheiro, B., Resende, R. O., Moriones, E., and Navas-Castillo, J. 2012. Genetic diversity and recombination analysis of 9 sweepoviruses from Brazil. Virol. J. 9:241.

Ateka, E. M., Njeru, R. W., Kibaru, A. G., Kimenju, J. W., Barg, E., Gibson, R. W., and Vetten, H. J. 2004. Identification and distribution of viruses infecting sweetpotato in Kenya. Ann. Appl. Biol. 144:371-379.
Beetham, P., and Mason, A. 1992. Production of Pathogen-Tested Sweet Potato. Australian Centre for International Agricultural Research, Canberra.

Briddon, R. W., Bull, S. E., and Bedford, I. D. 2006. Occurrence of Sweet potato leaf curl virus in Sicily. Plant Pathol. 55:286.

Bryan, A. D., Pesic-Van Esbroeck, Z., Schultheis, J. R., Pecota, K. V., Swallow, W. H., and Yencho, G. C. 2003. Cultivar decline in sweetpotato: I. Impact of micropropagation on yield, storage root quality, and virus incidence in 'Beauregard'. J. Am. Soc. Hortic. Sci. 128:846-855.

Clark, C. A., Davis, J. A., Abad, J. A., Cuellar, W. J., Fuentes, S., Kreuze, J. F., Gibson, R. W., Mukasa, S. B., Tugume, A. K., Tairo, F. D., and Valkonen, J. P. T. 2012. Sweetpotato viruses: 15 years of progress on understanding and managing complex diseases. Plant Dis. 96:168-185.

Clark, C. A., and Hoy, M. W. 2006. Effects of common viruses on yield and quality of Beauregard sweetpotato in Louisiana. Plant Dis. 90:83-88.

Cohen, J., and Loebenstein, G. 1991. Role of a whitefly-transmitted agent in infection of sweetpotato by cucumber mosaic virus. Plant Dis. 75:291-292.

Collins, W. W., Wilson, L. G., Arrendell, S., and Dickey, L. F. 1987. Genotype × environment interactions in sweetpotato yield and quality factors. J. Am. Soc. Hortic. Sci. 112:579-583.

Cuellar, W. J., Galvez, M., Fuentes, S., Tugume, J., and Kreuze, J. 2015. Synergistic interactions of begomoviruses with Sweetpotato chlorotic stunt virus (genus Crinivirus) in sweetpotato (Ipomoea batatas L.). Mol. Plant Pathol. 16:459-471

Dennien, S., Homare, D., Hughes, M., Lovatt, J., Coleman, E., and Jackson, G 2013. Growing Healthy Sweetpotato: Best Practices for Producing Planting Material. ACIAR Monograph No. 153. Australian Centre for International Agricultural Research, Canberra.

Domola, M. J., Thompson, G. J., Aveling, T. A. S, Laurie, S. M., Strydom, H., and van den Berg, A. A. 2008. Sweetpotato viruses in South Africa and the effect of viral infection on storage root yield. Afr. Plant Prot. 14:15-23.

Esterhuizen, L. L., Heerden, S. W., Rey, M. E. C., and Heerden, H. 2012. Genetic identification of two sweet-potato-infecting begomoviruses in South Africa Arch. Virol. 157:2241-2245.

Fauquet, C. M., and Stanley, J. 2003. Geminivirus classification and nomenclature: Progress and problems. Ann. Appl. Biol. 142:165-189.

Gibson, R. W., Kaitisha, G. C., Randrianaivoarivony, J. M., and Vetten, H. J. 1998 Identification of the East African strain of sweetpotato chlorotic stunt virus as a major component of sweet potato virus disease in southern Africa. Plant Dis. 82: 1063.

Gibson, R. W., and Kreuze, J. F. 2015. Degeneration in sweetpotato due to viruses, virus-cleaned planting material and reversion: A review. Plant Pathol. 64:1-15.

Gibson, R. W., Mwanga, R. O. M., Kasule, S., Mpembe, I., and Carey, E. E. 1997. Apparent absence of viruses in most symptomless field-grown sweetpotato in Uganda. Ann. Appl. Biol. 130:481-490.

Gruneberg, W. J., et al. 2015. Advances in sweet potato breeding from 1993 to 2012. Pages 1-77 in: Potato and Sweet Potato in Africa, Transforming the Value Chains for Food and Nutrition Security. J. Low, M. Nyongesa, S. Quinn, and M. Parker, eds. CABI, Wallingford, UK.

Gruneberg, W. J., Eyzaguirre, R., Espinoza, J., Mwanga, R. O., Andrade, M., Dapaah, H., Tumwegamire, S., Agili, S., Ndingo-Chipungu, F. P., Attaluri, S., Kapinga, R., Nguyen, T., Kaiyung, X., Tjintokohadi, K., Carey, T., and Low, J. 2010. Procedures for the Evaluation and Analysis of Sweetpotato Trials. International Potato Center, Lima, Peru.

Gurmu, F., Hussein, S., and Laing, M. 2014. The potential of orange-fleshed sweetpotato to prevent vitamin A deficiency in Africa. Int. J. Vitam. Nutr. Res. 84:65-78.

Gutiérrez, D. L., Fuentes, S., and Salazar, L. 2003. Sweetpotato virus disease (SPVD): Distribution, incidence and effect on sweetpotato yield in Peru. Plant Dis. 87:297-302.

Hahn, S. K., Terry, E. R., and Leuschner, K. 1981. Resistance of sweetpotato to virus complex (SPVD). Horticulture 16:535-537.

Hartmann, H. T., Kester, D. E., Davies, F. T., and Geneve, R. L. 1997. Plant Propagation: Principles and Practices, 6th ed. Prentice Hall, Upper Saddle River, NJ.

IsHak, J. A., Kreuze, J. F., Johansson, A., Mukasa, S. B., Tairo, F., El-Abbas, F. A., and Valkonen, J. P. T. 2003. Some molecular characteristics of three viruses from SPVD-affected sweetpotato plants in Egypt. Arch. Virol. 148:2449-2460.

Karyeija, R. F., Gibson, R. W., and Valkonen, J. P. T. 1998. The significance of sweetpotato feathery mottle virus in subsistence sweetpotato production in Africa. Plant Dis. 82:4-15.

Kays, S. J. 2005. Sweetpotato production worldwide: Assessment trends and the future. Acta Hortic.: 19-25.

Kim, J., Yang, J. W., Kwak, H. R., Kim, M. K., Seo, J. K., Chung, M. N., et al. 2017. Virus incidence of sweet potato in Korea from 2011 to 2014. Plant Pathol. J. 33:467-477.

Kurabachew, H. 2015. The role of orange fleshed sweet potato (Ipomea batatas) for combating vitamin A deficiency in Ethiopia: A review. Int. J. Food Sci Nutr. Eng. 5:141-146.

Kwak, H. R., Kim, M. K., Shin, J. C., Lee, Y. J., Seo, J. K., Lee, H. U., Jung, M. N., Kim, S. H., and Choi, H. S. 2014. The current incidence of viral disease in Korean sweet potatoes and development of multiplex RT-PCR assays for simultaneous detection of eight sweet potato viruses. Plant Pathol. J. 30: 416-424. 
Li, R., Salih, S., and Hurtt, S. 2004. Detection of geminiviruses in sweetpotato by polymerase chain reaction. Plant Dis. 88:1347-1351.

Ling, K.-S., Jackson, D. M., Harrison, H., Simmons, A. M., and Pesic-VanEsbroeck, Z. 2010. Field evaluation on the yield effects of U.S. heirloom sweetpotato cultivars infected by Sweetpotato leaf curl virus. Crop Prot. 29:757-765.

Lotrakul, P., Valverde, R. A., Clark, C. A., and Fauquet, C. 2003. Properties of a begomovirus isolated from sweetpotato [Ipomoea batatas (L.) Lam.] infected with Sweet potato leaf curl virus. Rev. Mex. Fitopatol. 21:128-136.

Lozano, G., Trenado, H. P., Valverde, R. A., and Navas-Castillo, J. 2009. Novel begomovirus species of recombinant nature in sweetpotato (Ipomoea batatas) and Ipomoea indica: Taxonomic and phylogenetic implications. J. Gen. Virol. 90:2550-2562.

Luan, Y. S., Zhang, J., and An, L. J. 2006. First report of Sweetpotato leaf curl virus in China. Plant Dis. 90:1111.

Maina, S. 2014. Detection, distribution and genetic diversity of sweetpotato leaf curl virus from western, coast and central regions of Kenya. M.Sc. thesis, Kenyatta University, Nairobi, Kenya.

Maina, S., Miano, D. W., Mbogo, E., Amimo, J. O., Irungu, J., and Njiruh, P. N. 2017. Occurrence and genetic variability of partial coat protein gene of Sweet potato leaf curl virus (SPLCV) in Kenya. Afr. J. Biotechnol. 16:2112-2120.

Miano, D. W., LaBonte, D. R., Clark, C. A., Valverde, R. A., and Hoy, M. W. 2006. First report of a begomovirus infecting sweetpotato in Kenya. Plant Dis. 90:832.

Milgram, M., Cohen, J., and Loebenstein, G. 1996. Effects of sweetpotato feathery mottle virus and sweetpotato sunken vein virus on sweetpotato yields and rates of reinfection of virus-free planting material in Israel. Phytoparasitica 24:189-193.

Motsa, N. M., Modi, A. T., and Mabhaudhi, T. 2015. Sweet potato (Ipomoea batatas Lam) as a drought tolerant and food security crop. S. Afr. J. Sci. 111:1-8.

Mukasa, S. B. 2004. Genetic Variability and Interactions of Three Sweetpotato Infecting Viruses. Ph.D. thesis, Swedish University of Agricultural Sciences, Uppsala.

Mulabisana, J., Cloete, M., Laurie, S., Mphela, W. M., Maserumule, M. M., Nhlapo, T., Cochrane, N. M., Oelofse, D., and Rey, C. 2019. Yield evaluation of multiple and co-infections of begomoviruses and potyviruses on sweet potato varieties under field conditions and confirmation of multiple infection by NGS. Crop Prot. 119:102-112.

Musembi, K. B., Githiri, S. M., Yencho, G. C., and Sibiya, J. 2015. Combining ability and heterosis for yield and drought tolerance traits under managed drought stress in sweetpotato. Euphytica 201:423-440.
Mwanga, R. O., Odongo, B., Niringiye, C., Alajo, A., Abidin, P. E., Kapinga, R. and Carey, E. E. 2007. Release of two orange-fleshed sweetpotato cultivars; SPK004 - "Kakamega" and "Ejumula", in Uganda. HortScience 42:1728-1730.

Ngeve, J. M., and Bouwkamp, J. C. 1993. Comparison of statistical methods to assess yield stability in sweetpotato. J. Am. Soc. Hortic. Sci. 118:304-310.

Njeru, R. W., Mburu, M. W. K., Cheramgoi, E., et al. 2004. Studies on the physiological effects of viruses on sweet potato yield in Kenya. Ann. Appl. Biol. 145:71-76.

Paprotka, T., Boiteux, L. S., Fonseca, M. E., Jeske, H., Faria, J. C., and Riberio, S. G. 2010. Genomic diversity of sweet potato geminiviruses in a Brazilian germplasm bank. Virus Res. 149:224-233.

Prasanth, G., and Hegde, V. 2008. Occurrence of sweetpotato feathery mottle virus and Sweet potato leaf curl Georgia virus on sweetpotato in India. Plant Dis. 92: 311.

Roitsch, T., Balibrea, M. E., Hofmann, M., Proels, R., and Sinha, A. K. 2003. Extracellular invertase: Key metabolic enzyme and PR protein. J. Exp. Bot. 54:513-524.

Simmons, A. M., Harrison, H. F., and Ling, K.-S. 2008. Forty-nine new host plant species for Bemisia tabaci (Hemiptera: Aleyrodidae). Entomol. Sci. 11: 385-390.

Tairo, F., Mukasa, S. B., Jones, R. C., Kullaya, A., Rubaihayo, P. R., and Valkonen, J. P. T. 2005. Unravelling the genetic diversity of the three main viruses involved in sweetpotato virus disease (SPVD), and its practical implications. Mol. Plant Pathol. 6:199-211.

Tugume, A. K., Amayo, R., Weinheimer, I., Mukasa, S. B., Rubaihayo, P. R., et al. 2013. Genetic variability and evolutionary implications of RNA silencing suppressor genes in RNA1 of Sweet potato chlorotic stunt virus isolates infecting sweetpotato and related wild species. PLoS One 8:e81479.

Untiveros, M., Fuentes, S., and Salazar, L. F. 2007. Synergistic interaction of Sweetpotato chlorotic stunt virus (Crinivirus) with carla-, cucumo-, ipomo-, and potyviruses infecting sweetpotato. Plant Dis. 91:669-676.

Wang, H.-L., Lei, T., Xia, W.-Q., et al. 2019. Insight into the microbial world of Bemisia tabaci cryptic species complex and its relationships with its host. Sci. Rep. 9:6568.

Wasswa, P., Otto, B., Maruthi, M., Mukasa, S., Monger, W., and Gibson, R. 2011. First identification of a sweetpotato begomovirus (sweepovirus) in Uganda: Characterization, detection and distribution. Plant Pathol. 60: 1030-1039. 